\title{
Studies on Cassava (Manihot esculenta Crantz) Intercropped with Fodder Cowpea (Vigna sinensis L.) in Sandy Soil
}

\author{
Sahar A. Sherif and Azza Kh. Salem* \\ Crop Intensification Research Section and *Forage Crop \\ Research Section,Field Crops Research Instution, Agricultural \\ Research Centre (ARC), Giza, Egypt.
}

\begin{abstract}
7 IELD trials were carried out in a newly reclaimed sandy soil at South Tahrir Research Station, during 2008/2009 and 2009/2010 seasons to study the response of intercropping fodder cowpea (Vigna unguiculata L.) with cassava (Manihot esculenta Crantz) at different plant spacing of cassava $(1.0 \mathrm{~m} \times 1.5 \mathrm{~m}, 1.0 \mathrm{~m} \times 1.0 \mathrm{~m}$ and $1.0 \mathrm{~m} \times 0.75 \mathrm{~m})$ and three plant density of fodder cowpea $(21000,28000$ and 42000 plants/fed) on growth, yield and yield components of both crops. A split plot design was used with three replicates. The effect of cassava plant spacing indicated that maximum yield of cassava tubers was associated with lowest cassava spacing $(1.0 \mathrm{~m} \times 0.75 \mathrm{~m})$ associated with highest cowpea plant density (42000 plants/fed) in both seasons. Whereas, the maximum yield of cowpea forage yield was observed when fodder cowpea was intercropped with cassava under highest cassava plant spacing $(1.0 \mathrm{~m} \times 1.5 \mathrm{~m})$ associated with highest plant density of cowpea (42000 plants/fed) in the two seasons. Maximum value of land equivalent ratio (LER) 1.66 and 1.70 were recorded when cassava was planted at $1.0 \mathrm{~m} \times 0.75 \mathrm{~m}$ intercropped with cowpea at highest population density (42000 plants/fed) in the two seasons. Cassava was the dominated crop when intercropped with cowpea in most cases.
\end{abstract}

Key words: Intercropping, Plant spaces, Cassava, (Manihot esculenta Crantz), Fodder cowpea (Vigna unguiculata L.), Land equivalent ratio (LER)

Maximize land productivity is becoming more important because of the higher population pressure and other human activities competing with agriculture for the limited available land (Steiner, 1991).

Cassava (Manihot esculenta Crantz) is an important root crop often found in mixtures with other crop plants. In the southern parts of Nigeria, intercropping cassava and cereals or grain legumes is widely practiced by smallholders. When cassava intercropped with maize (Zea mays L.) or cowpea (Vigna unguiculata L.) it is usually regarded as the main crop for yield. Cassava often planted later of the rainy season to minimize competition with the other crops which are more sensitive to soil fertility and moisture (Okigbo, 1980). 
Cassava is often left for continue growing after the other short duration crops, such as maize when have been harvested in the early season. Some farmers however, plant a few stands of other vegetables in the cassava farm in late season when the canopy has not closed. Leguminous crop like cowpea could be cultivated in late season because of their inherent advantages such as short growth period; low canopy plant structure; drought tolerance; as well as ability to fix atmospheric $\mathrm{N}$ in their root nodules, which make it highly advantageous to grow in relay or mixed cropping systems (Aigh, 2007 and Njoku et al., 2010).

On other hand, mixed cropping specially with legumes can improve forge quality and yield because legumes are good source of protein (Moreira, 1989).

According to Ikeorgu \& Odurukwe (1990), the performance of cassava/ legume association is dependent upon the population density of the legume. The authors suggested that there is a great need to determine the optimum population density of various legumes intercropped with cassava for better cassava production. On other hand, Ayoola \& Makinde (2008) found that cowpea yield was reduced with decreasing cassava plant spacing when cassava intercropped with maize as a relayed with cowpea under different cassava plant spacing $(0.9 \mathrm{~m}$ x $0.9 \mathrm{~m}, 1.0 \mathrm{~m} \times 1.0 \mathrm{~m}, 1.5 \mathrm{~m} \times 0.75 \mathrm{~m}$ and $1.5 \mathrm{~m} \times 1.0 \mathrm{~m}$ ), whereas, cassava root yield was increased with decreasing the cassava plant spacing to $0.9 \mathrm{~m} \mathrm{x} 0.9 \mathrm{~m}$.

Intercropping can be beneficial in increasing crop yield and land use efficiency, Amanullah et al. (2006b). found that both cassava-cowpea and peanut associations resulted in land equivalent ratios (LERs) between 1.38 and 1.56, respectively. Fonseca (1981), observed that intercropping cassava and peanut resulted in $40-70 \%$ greater land use efficiency (LUE) value than when the two crops were grown alone.

Cenpukdee \& Fukai (1992) and Sherif (2000) found lower values of the relative yield of the base crops when associated with cassava due to the interspecific competition where intercropping cassava in most cases resulted in higher values of land equivalent ratio. On other hand, Abd El-Shafy et al. (2009), reported that when intercropped teosinte (Zea Mexicana Schard) with cowpea, teosinte had the highest values of relative yield (RY) which was the dominant. While, cowpea had the lowest values and it was the dominated crop.

This investigation aimed to study the possibility of increasing green summer forage productivity and its return under sandy soil when intercropping cowpea as a leguminous fodder crops with cassava.

\section{Material and Methods}

Two field trials were carried out in newly reclaimed sandy soil at South Tahrir Research Station, during 2008/2009 and 2009/2010 seasons to study the effect of cassava plant spacing which intercropped with fodder cowpea under 
different fodder cowpea plant density on growth, yield components and yield of each of the two crops. The treatments were as follows:

\section{Cassava plant spacing in intercropping}

- $\mathrm{S} 1=1.0 \mathrm{~m} \times 1.5 \mathrm{~m}$ (Cassava stakes were spaced at $1.0 \mathrm{~m} \times 1.5 \mathrm{~m}$ )

- $\mathrm{S} 2=1.0 \mathrm{~m} \times 1.0 \mathrm{~m}$ (Cassava stakes were spaced at $1.0 \mathrm{~m} \times 1.0 \mathrm{~m})$

- $\mathrm{S} 3=1.0 \mathrm{~m} \times 0.75 \mathrm{~m}$ (Cassava stakes were spaced at $1.0 \mathrm{~m} \times 0.75 \mathrm{~m})$

Pure cassava was planted at a distance of $1.0 \mathrm{~m} \times 1.0 \mathrm{~m}$

Cowpea plant densities:

- $\mathrm{D} 1=21000$ plants/fed (cowpea was sown at $40 \mathrm{~cm}$. , two plants/hill)

- $\mathrm{D} 2=28000$ plants $/ \mathrm{fed}$ (cowpea was sown at $30 \mathrm{~cm}$. apart, two plants $/$ hill)

- $\mathrm{D} 3=42000$ plants/fed (cowpea was sown at $20 \mathrm{~cm}$ apart, two plants/hill)

Pure cowpea was sown on rows of $60 \mathrm{~cm}$ apart at a distance of $25 \mathrm{~cm}$ between hills and thinned to two plants/hill (56000 plant/fed).

The mechanical and chemical analysis of the experimental soil are presented in Table 1.

TABLE 1. Mechanical and chemical analysis of the experimental soil.

\begin{tabular}{|c|c|c|c|c|c|c|c|c|c|c|c|c|c|}
\hline \multirow{2}{*}{$\begin{array}{c}\text { Soil } \\
\text { depth } \\
\text { (cm) }\end{array}$} & \multirow{2}{*}{$\begin{array}{c}\text { EC } \\
\text { dsm }^{-1}\end{array}$} & \multirow[b]{2}{*}{ pH } & \multicolumn{4}{|c|}{$\begin{array}{c}\text { Soluble cations } \\
(\mathrm{meq} / \mathrm{L})\end{array}$} & \multicolumn{3}{|c|}{$\begin{array}{c}\text { Soluble anions } \\
(\mathrm{meq} / \mathrm{L})\end{array}$} & \multicolumn{4}{|c|}{ Mechanical analysis } \\
\hline & & & $\mathrm{Ca}^{+2}$ & $\mathrm{Mg}^{+2}$ & $\mathrm{Na}^{+}$ & $\mathbf{K}^{+}$ & $\mathrm{HCO}^{-3}$ & $\mathrm{Cl}^{-}$ & $\mathrm{SO}_{4}^{-2}$ & $\begin{array}{c}\text { Sand } \\
\%\end{array}$ & $\begin{array}{c}\text { Silt } \\
\%\end{array}$ & $\begin{array}{c}\text { Clay } \\
\%\end{array}$ & $\begin{array}{c}\text { Texture } \\
\text { class }\end{array}$ \\
\hline $0-30$ & 1.38 & 7.83 & 5.75 & 4.60 & 3.60 & 0.20 & 4.60 & 6.80 & 2.75 & 90.30 & 3.60 & 5.50 & Sandy \\
\hline
\end{tabular}

The experiment was laid out in a split plot design with three replicates. Cassava spacing occupied the main plots, whereas, cowpea population densities occupied the subplots. All treatments were assigned at random to their respective plots. Plot size was $7 \mathrm{x} 4 \mathrm{~m}\left(28 \mathrm{~m}^{2}\right)$.

Cassava stem cuttings of Brazilian cultivar obtained from Ismaillia Research Station were planted on $1^{\text {st }}$ April in the two seasons. Cuttings were of similar thickness $25-30 \mathrm{~cm}$ in length and inserted vertically in the soil with two thirds into the soil keeping one third over ground, then irrigated after planting directly. A drip irrigation system with nozzles of $50 \mathrm{~cm}$ apart was adopted for irrigation. Phosphorus fertilizer was added during land preparation at a rate of $50 \mathrm{~kg}$ $\mathrm{P}_{2} \mathrm{O}_{5} / \mathrm{fed}$ in the form of calcium superphosphate $\left(15 \% \mathrm{P}_{2} 0_{5}\right)$. Nitrogen fertilizer in the form of ammonium nitrate $(33.5 \% \mathrm{~N})$ at a rate of $50 \mathrm{~kg} \mathrm{~N} / \mathrm{fed}$ was divided into 4 equal doses. Potassium in the form of potassium sulphate $\left(48 \% \mathrm{~K}_{2} 0\right)$ was added at the rate of $96 \mathrm{~kg} \mathrm{~K}_{2} \mathrm{O} / \mathrm{fed}$ and divided into 6 equal doses. Fertilization program started from the third week after planting. Cassava roots were harvested 11 months after planting on 5 and $10^{\text {th }}$ February in the two seasons, respectively. All agricultural practices needed for growing cassava plant and fodder cowpea were practiced. 
Fodder cowpea c.v.(Vigna sinensis) was sown on $1^{\text {st }}$ and $5^{\text {th }}$ May in the first and second seasons, respectively. All cultural practices for growing cowpea in the intercropped and solid plantation were followed as recommended. Three cuts were taken at 50,90 and 135 days after sowing.

The following data were recorded:

For cassava: One week before harvesting, five guarded plants were taken randomly from each plot to determine plant height $(\mathrm{cm})$, number of tubers/plant, length and diameter of tubers $(\mathrm{cm})$, tuber weight $(\mathrm{kg} / \mathrm{plant})$ and tuber yield (ton/fed).

For fodder cowpea: From each cut, five plants were taken randomly from each plot and the following data was recorded: Plant height $(\mathrm{cm})$, number of branches and leaves/plant, fresh forage and dry yield (ton/fed) .

\section{Competitive relationships}

Land equivalent ratio (LER)

As described by Mead \& Willey (1980), was as follows:

$$
\operatorname{LER}=\sum_{\mathbf{i}=\mathbf{1}}{ }^{\mathbf{n}}\left(\mathbf{Y}_{\mathbf{i}} \mathbf{I}^{\mathbf{M}} \mathbf{Y}_{\mathbf{i}}^{\mathbf{M}}\right)
$$

where $Y_{i}{ }^{I}=$ Yield of crop $i$ in intercropping

$$
\begin{aligned}
& \mathrm{Y}_{\mathrm{i}}{ }^{\mathrm{M}}=\text { Yield of crop } \mathrm{i} \text { in monocropping, } \\
& \mathrm{n}=\text { Number of crops in the intercropping system }
\end{aligned}
$$

Aggressivity (A)

Aggressivity value was calculated by the formula proposed by Mc- Gilichrist (1965):

$$
A_{a b}=\frac{Y_{a b}}{Y_{a a} \times Z_{a b}}-\frac{Y_{b a}}{Y_{b b} \times Z_{b a}}
$$

where, $A a b=$ Aggressivity value for the components "a". Yaa is pure stand yield of crop a, Ybb is pure stand yield of crop b, Yab is mixture yield of a (when combined with $b$ ) and Yba yield of $b$ (when combined with $a)$.

$\mathrm{Z}_{\mathrm{ab}}$ is sown proportion of species a (in a mixture with $\mathrm{b}$ ) and $\mathrm{Z}_{\mathrm{ba}}$ is sown proportion of species $b$ (in a mixture with $a$ ).

Competitive ratio $(C R)$

Competitive ratio was calculated by the formula proposed by Willey \& Rao (1980). The CR of crop b is the reciprocal of the CR of crop a.

$$
\mathrm{CR}_{\mathrm{a}}=\left(\mathrm{LER}_{\mathrm{a}} / \mathrm{LER}_{\mathrm{b}}\right)\left(\mathrm{S}_{\mathrm{b}} / \mathrm{S}_{\mathrm{a}}\right)
$$

where: $S_{a}=$ Relative space occupied by crop a

$\mathrm{Sb}=$ Relative space occupied by crop $\mathrm{b}$ 
All data were statistically analyzed according to Snedecor \& Cochran (1982), using MSTAT- Computer Statistical Software (1986). L.S.D 0.05 level of probability was used to compare between treatment means.

\section{Results and Discutions}

\section{Cassava}

Effect cassava spacing between plants on growth, yield and its components

Data in Table 2 indicated that plant height was statistically influenced by plant spacing. Increasing distances between plants decreased plant height. These results were true in the two seasons. Increase plant height with decreasing plant spacing might be due to less competition between plants had have their needs from light which resulted in increase in the internodes length. Similar results supported by Khalil (1995), who reported that narrowing spacing produced taller plants as compared with wide spacing. On other hand, number of branches per plant followed a reversal trend. Data revealed substantial increases in the average number of total branches per plant with increasing distance between plants. Leihner (1983), reported that the deleterious effect of growing cassava at higher plant density lies in the fact that plant produced greater number of primary stems per unit area of land which lead to the increase in competition within these stems at the later growth stages.

TABLE 2. Effect cassava spacing between plants on its yield and yield components .

\begin{tabular}{|c|c|c|c|c|c|c|c|}
\hline Treatments & $\begin{array}{c}\text { Plant } \\
\text { height } \\
(\mathrm{cm})\end{array}$ & $\begin{array}{c}\text { No. of } \\
\text { total } \\
\text { branches / } \\
\text { plant }\end{array}$ & $\begin{array}{c}\text { No. of } \\
\text { tubers/ } \\
\text { plant }\end{array}$ & $\begin{array}{l}\text { Length } \\
\text { of } \\
\text { tubers } \\
(\mathrm{cm})\end{array}$ & $\begin{array}{c}\text { Diameters } \\
\text { of } \\
\text { tubers } \\
(\mathrm{cm})\end{array}$ & $\begin{array}{c}\text { Wt. of } \\
\text { tubers } \\
\text { (kg.) } \\
\text { plant }\end{array}$ & $\begin{array}{l}\text { Tuber } \\
\text { yield } \\
\text { ton/ } \\
\text { fed }\end{array}$ \\
\hline $\begin{array}{c}\text { Cassava plant } \\
\text { spacing }\end{array}$ & \multicolumn{7}{|c|}{$2008 / 2009$} \\
\hline $\mathrm{S} 1$ & 137.22 & 3.30 & 3.60 & 22.98 & 2.36 & 2.92 & 8.33 \\
\hline S2 & 147.28 & 2.69 & 4.13 & 27.64 & 2.20 & 2.28 & 9.53 \\
\hline S3 & 162.83 & 1.96 & 4.65 & 34.56 & 1.88 & 1.95 & 16.94 \\
\hline L.S.D. 0.05 & 17.86 & 0.52 & 0.29 & 1.80 & 0.23 & 0.59 & 1.37 \\
\hline \multicolumn{8}{|c|}{$2009 / 2010$} \\
\hline S1 & 142.56 & 3.70 & 3.78 & 28.00 & 2.75 & 3.33 & 9.36 \\
\hline S2 & 153.67 & 3.08 & 4.42 & 31.00 & 2.36 & 2.87 & 10.31 \\
\hline S3 & 172.22 & 2.28 & 4.90 & 33.78 & 2.09 & 2.09 & 17.53 \\
\hline L.S.D. 0.05 & 20.78 & 0.49 & 0.45 & 3.71 & 0.23 & 0.63 & 2.45 \\
\hline
\end{tabular}

Number of tubers per plant and length of tubers were associated with plant spacing. Highest values were obtained with the lowest space $(\mathrm{S} 3=1.0 \mathrm{~m} x$ $0.75 \mathrm{~m})$. Whereas, diameter of tubers behaved in another trend. The values of tuber diameters at higher space $(\mathrm{S} 1=1.0 \mathrm{~m} \times 1.5 \mathrm{~m})$ were higher than that obtained from low spacing ( $\mathrm{S} 3=1.0 \mathrm{~m} \times 0.75 \mathrm{~m}$ ). This could be due to the widen space at lower population densities for developing bigger sized cassava tubers. (IITA, 1985). It has been observed that farmers are more interested in bigger-sized tubers because they could be peeled faster and easier than smaller ones. In 
addition, tuber weight was increased with increasing spaces between plants. However, differences among imposed treatments were statistically significant. These results hold true in the two growing seasons and supported by Ayoola \& Makinde (2008). On other hand, tuber yield per fed was tenaciously bounded with plant spacing. Lowest cassava spacing $(\mathrm{S} 3=1.0 \mathrm{~m} \times 0.75 \mathrm{~m})$ gave highest yield. These results were also true in the two seasons. The increase in tuber yield when cassava was planted at $(1.0 \mathrm{~m} \times 0.75 \mathrm{~m})$ was over $(1.0 \mathrm{~m} \times 1.5 \mathrm{~m})$ were estimated to be 103.36 and $87.29 \%$ in the first and second seasons, respectively. These results were in agreement with previous investigators (Ibrahim et al.,2004).

Effect of plant densities of fodder cowpea on cassava yield and its components

Data in Table 3 showed that the larger fodder cowpea density (D3= 42000plant/fed) had higher values than the lower density (D1=21000plant/fed) for almost traits in the two seasons. The lower value of cassava when intercropped with cowpea could be due to the modification of the soil microenvironment at full coverage of cowpea as reported by Ikeorgu \& Odurukwe (1990). There was significant effect of fodder cowpea plant densities on the plant height and number of branches in each of the two seasons. The increase of cassava plant height with increasing fodder cowpea plant densities might be due to more crowding and competitions for light and the other essential requirements for growth and developments. These results were true in each of the two growing seasons. Number of total branches of cassava per plants behaved another trend. More branching was associated when cassava intercropped with fodder cowpea at the lowest density $(\mathrm{D} 1=21000$ plant/fed) in the two seasons. This trend might be due to the higher competition between cassava plants and fodder cowpea. Similar results were regarded by Cenpukdee \& Fukai (1992).

TABLE 3. Effect of fodder cowpea plant densities on cassava yield and its components.

\begin{tabular}{|c|c|c|c|c|c|c|c|}
\hline Characters & $\begin{array}{c}\text { Plant } \\
\text { height } \\
(\mathbf{c m})\end{array}$ & $\begin{array}{c}\text { No. of total } \\
\text { branches/ } \\
\text { plant }\end{array}$ & $\begin{array}{c}\text { No. of } \\
\text { tubers/plant }\end{array}$ & $\begin{array}{c}\text { Length } \\
\text { of } \\
\text { tubers } \\
(\mathrm{cm}) \\
\end{array}$ & $\begin{array}{c}\text { Diameters } \\
\text { of } \\
\text { tubers } \\
(\mathbf{c m})\end{array}$ & $\begin{array}{c}\begin{array}{c}\text { Wt. of } \\
\text { tubers } \\
(\mathrm{kg})\end{array} \\
\text { plant }\end{array}$ & $\begin{array}{c}\text { Tuber } \\
\text { yield } \\
\text { ton/ } \\
\text { fed } \\
\end{array}$ \\
\hline $\begin{array}{c}\text { Cowpea } \\
\text { densities }\end{array}$ & \multicolumn{7}{|c|}{$2008 / 2009$ growing season } \\
\hline D1 & 133.39 & 3.55 & 3.25 & 24.83 & 2.82 & 2.01 & 10.09 \\
\hline D2 & 149.44 & 2.50 & 4.06 & 28.53 & 1.98 & 2.31 & 11.54 \\
\hline D3 & 164.50 & 1.91 & 5.07 & 31.81 & 1.63 & 2.83 & 13.17 \\
\hline L.S.D. 0.05 & 4.48 & 0.40 & 0.41 & 3.84 & 0.22 & 0.28 & 1.59 \\
\hline \multicolumn{8}{|c|}{ 2009/2010 growing season } \\
\hline D1 & 140.56 & 4.01 & 3.44 & 28.06 & 3.03 & 2.23 & 10.98 \\
\hline D2 & 157.33 & 2.75 & 4.25 & 31.39 & 2.33 & 2.69 & 12.36 \\
\hline D3 & 170.56 & 2.31 & 5.40 & 33.33 & 1.83 & 3.28 & 13.94 \\
\hline L.S.D. 0.05 & 16.15 & 0.29 & 0.34 & 2.10 & 0.19 & 0.19 & 1.11 \\
\hline
\end{tabular}

The effect of fodder cowpea plant density on total number of tubers, diameter and length of tubers, weight of tubers per plant as well as yield of tubers per feddan in the

Egypt. J. Agron. 33, No. 1 (2011) 
two seasons was significant. While diameter of tuber decreased by increasing fodder cowpea plant density the length of tuber was increased, in the two seasons. Highest values of number and weight of tubers per plant were associated with the highest plant density (D3= 42000plant/fed) of fodder cowpea. Also, data indicated that cassava tuber yield per fed increased with increasing plant density of fodder cowpea. The excess in cassava tuber yield at highest density of fodder cowpea over those grown at lowest density of fodder cowpea were estimated to 30.52 and $26.96 \%$ in first and second seasons, respectively. These results agree with the findings of Udeata (2005) and Kurtz (2006). This observation suggests that the presence of the legumes in the cassava/legume mixtures may have been beneficial to cassava crop. The beneficial effects of legumes stem from their enriching soil by improving the soil $\mathrm{N}$ status, as legumes have the ability to fix $\mathrm{N}$ into the soil (Aigh, 2007 and Njoku et al. 2010). Another factor that can be implicated for the significant yield differences is the increase in soil organic matter (SOM) in the cassava/legume mixture, resulting from the decomposition of biomass produced by cassava and the legumes (Gerh et al., 2006). Further, the combined interference of both cassava and legumes on weed, due perhaps, to toxic chemicals (allelochemicals) secreted by cassava and legumes, as well as cassava and cowpea competing with weeds for growth resources (air, water, nutrients) might results in improving yield of cassava (Zoufa et al., 1992).

Interaction effect cassava spacing between plants and fodder cowpea plant densities on cassava yield, and its components

Data in Table 4 indicated that yield and yield components of cassava plants were non significantly affected by the interaction between the two variables except in case of the number of total branches per plant in second season. Furthermore, the highest yield per fed was obtained when the lowest cassava spacing $(\mathrm{S} 3=1.0 \mathrm{~m} \times 0.75 \mathrm{~m})$ were associated with highest fodder cowpea plant density (D3= 4200plant/fed). While the lowest values were associated with the highest cassava spacing $(\mathrm{S} 1=1.0 \mathrm{~m} \times 1.5 \mathrm{~m})$ with the lowest fodder cowpea plant density (D1=2100 plant/fed). These results were true in the two seasons.

\section{Fodder cowpea}

Effect cassava spacing between plants on cowpea yield and its components

Data in Table 5 revealed that all fodder cowpea traits under study were affected significantly by cassava plant spacing, except in cases of plant height in the first cut in the first season and number of leaves per plant in the first cut in the second season. Data revealed also that increasing distances between cassava plants causes gradual decreases in fodder cowpea heights. These results were true in the two seasons, as well as, in the three forage cuts. These results might be due the competition between plants for light. On other hand, all the studied traits followed different trend. The highest values were associated with highest cassava spacing $(\mathrm{S} 1=1.0 \mathrm{~m} \times 1.5 \mathrm{~m})$. The reduction in all traits were noticed when narrowing the distance between cassava plants might be due to shading by the associated cassava as a main crop for light competition (Leihner, 1983). 
TABLE 4. Interaction effect of cassava spacing between plants and fodder cowpea population densities on cassava yield, and its components.

\begin{tabular}{|c|c|c|c|c|c|c|c|c|}
\hline \multicolumn{2}{|r|}{ ters } & $\begin{array}{c}\text { Plant } \\
\text { height } \\
(\mathrm{cm})\end{array}$ & $\begin{array}{c}\text { No. of } \\
\text { total } \\
\text { branches/ } \\
\text { plant }\end{array}$ & $\begin{array}{c}\text { No. of } \\
\text { tubers/ } \\
\text { plant }\end{array}$ & $\begin{array}{c}\text { Length of } \\
\text { tubers } \\
(\mathrm{cm})\end{array}$ & $\begin{array}{c}\text { Diameters } \\
\text { of tubers } \\
(\mathrm{cm})\end{array}$ & $\begin{array}{c}\text { Wt. of } \\
\text { tubers } \\
\text { (kg) plant }\end{array}$ & $\begin{array}{c}\text { Tuber } \\
\text { yield } \\
\text { ton/fed }\end{array}$ \\
\hline $\begin{array}{c}\text { Cassava } \\
\text { plant } \\
\text { spacing } \\
\end{array}$ & $\begin{array}{l}\text { Cowpea } \\
\text { densities }\end{array}$ & & & & $2008 / 2009$ & & & \\
\hline \multirow{3}{*}{ S1 } & D1 & 123.33 & 4.57 & 2.75 & 19.50 & 3.03 & 2.42 & 7.08 \\
\hline & D2 & 140.00 & 3.08 & 3.58 & 23.10 & 2.27 & 2.75 & 8.33 \\
\hline & $\underline{\underline{D}} 3$ & 148.33 & 2.25 & 4.47 & 26.33 & 1.77 & 3.58 & 9.58 \\
\hline \multirow{3}{*}{$\mathrm{S} 2$} & D1 & 128.50 & 3.58 & 3.25 & 24.33 & 2.87 & 1.83 & 8.37 \\
\hline & D2 & 150.00 & 2.50 & 4.07 & 27.50 & 2.03 & 2.25 & 9.47 \\
\hline & D3 & 163.33 & 2.00 & 5.07 & 31.08 & 1.70 & 2.75 & 10.75 \\
\hline \multirow{3}{*}{ S3 } & D1 & 148.33 & 2.50 & 3.75 & 30.67 & 2.57 & 1.77 & 14.83 \\
\hline & D2 & 158.33 & 1.92 & 4.53 & 35.00 & 1.63 & 1.92 & 16.83 \\
\hline & D3 & 181.83 & 1.47 & 5.67 & 38.00 & 1.43 & 2.17 & 19.17 \\
\hline \multicolumn{2}{|c|}{ L.S.D. 0.05} & N. S & N.S & N. S & N.S & N.S & N.S & N.S \\
\hline \multicolumn{2}{|c|}{ C.V. } & 9.02 & 14.55 & 9.57 & 13.17 & 9.79 & 11.29 & 13.35 \\
\hline \multicolumn{2}{|c|}{ Solid } & & & & & & & 15.0 \\
\hline \multicolumn{9}{|c|}{$2009 / 2010$} \\
\hline \multirow{3}{*}{ S1 } & D1 & 126.67 & 4.93 & 2.83 & \begin{tabular}{|l|}
25.83 \\
\end{tabular} & 3.33 & 2.75 & 8.00 \\
\hline & $\mathrm{D} 2$ & 146.00 & 3.42 & 2.83 & 27.50 & 2.75 & 3.25 & 9.42 \\
\hline & $\underline{\underline{D}} 3$ & 155.00 & 2.75 & 4.67 & 30.67 & 2.17 & 4.00 & 10.67 \\
\hline \multirow{3}{*}{$\mathrm{S} 2$} & D1 & 136.67 & 4.25 & 3.50 & 28.33 & 3.00 & 2.48 & 9.17 \\
\hline & $\mathrm{D} 2$ & 156.00 & 2.58 & 4.25 & 31.33 & 2.27 & 2.88 & 10.25 \\
\hline & $\underline{\underline{D}} 3$ & 168.33 & 2.42 & 5.50 & 33.33 & 1.80 & 3.25 & 11.50 \\
\hline \multirow{3}{*}{ S3 } & D1 & 158.33 & 2.83 & 4.00 & 30.00 & 2.77 & 1.77 & 15.50 \\
\hline & $\mathrm{D} 2$ & 170.00 & 2.25 & 4.67 & 35.33 & 1.97 & 1.93 & 14.42 \\
\hline & $\underline{\underline{\mathrm{D}} 3}$ & 188.33 & 1.77 & 6.03 & 36.00 & 1.53 & 2.58 & 19.67 \\
\hline \multicolumn{2}{|c|}{ L.S.D. 0.05} & N.S & 0.50 & N. S & N.S & N.S & N.S & N. S \\
\hline \multicolumn{2}{|c|}{ C.V. } & 10.07 & 9.38 & 7.48 & 6.51 & 7.65 & 6.83 & 8.74 \\
\hline \multicolumn{2}{|c|}{ Solid } & \multicolumn{7}{|r|}{14.25} \\
\hline $\begin{array}{l}1=1.0 \mathrm{~m} \times \\
1=21000\end{array}$ & $\begin{array}{l}5 \mathrm{~m} \\
\text { ant/fed }\end{array}$ & & $\begin{array}{l}\mathrm{S} 2=1.0 \mathrm{~m} \\
\mathrm{D} 2=2800\end{array}$ & $\begin{array}{l}1.0 \mathrm{~m} \\
\text { plant/fed }\end{array}$ & & $\begin{array}{l}\text { S3 }= \\
\text { D3= }\end{array}$ & $\begin{array}{l}\mathrm{m} \times 0.75 \\
\text { 000plant/fe }\end{array}$ & \\
\hline
\end{tabular}

Fodder cowpea fresh and dry yield per fed were higher at the highest cassava spacing $(\mathrm{S} 1=1.0 \mathrm{~m} \times 1.5 \mathrm{~m})$. This could be attributed to lesser competition and low shading of cassava plants on cowpea (Muleba \& Ezumah, 1985). The increases in total fresh forge yield per fed at the highest cassava spacing $(\mathrm{S} 1=1.0 \mathrm{~m} \times 1.5 \mathrm{~m})$ over those grown at the lowest cassava spacing ( $\mathrm{S} 3=1.0 \times 0.75 \mathrm{~m}$ ) were estimated to 52.22 and $63.76 \%$ in the first and second seasons, respectively. 
STUDIES ON CASSAVA (MANIHOT ESCULENTA CRANTZ) ...

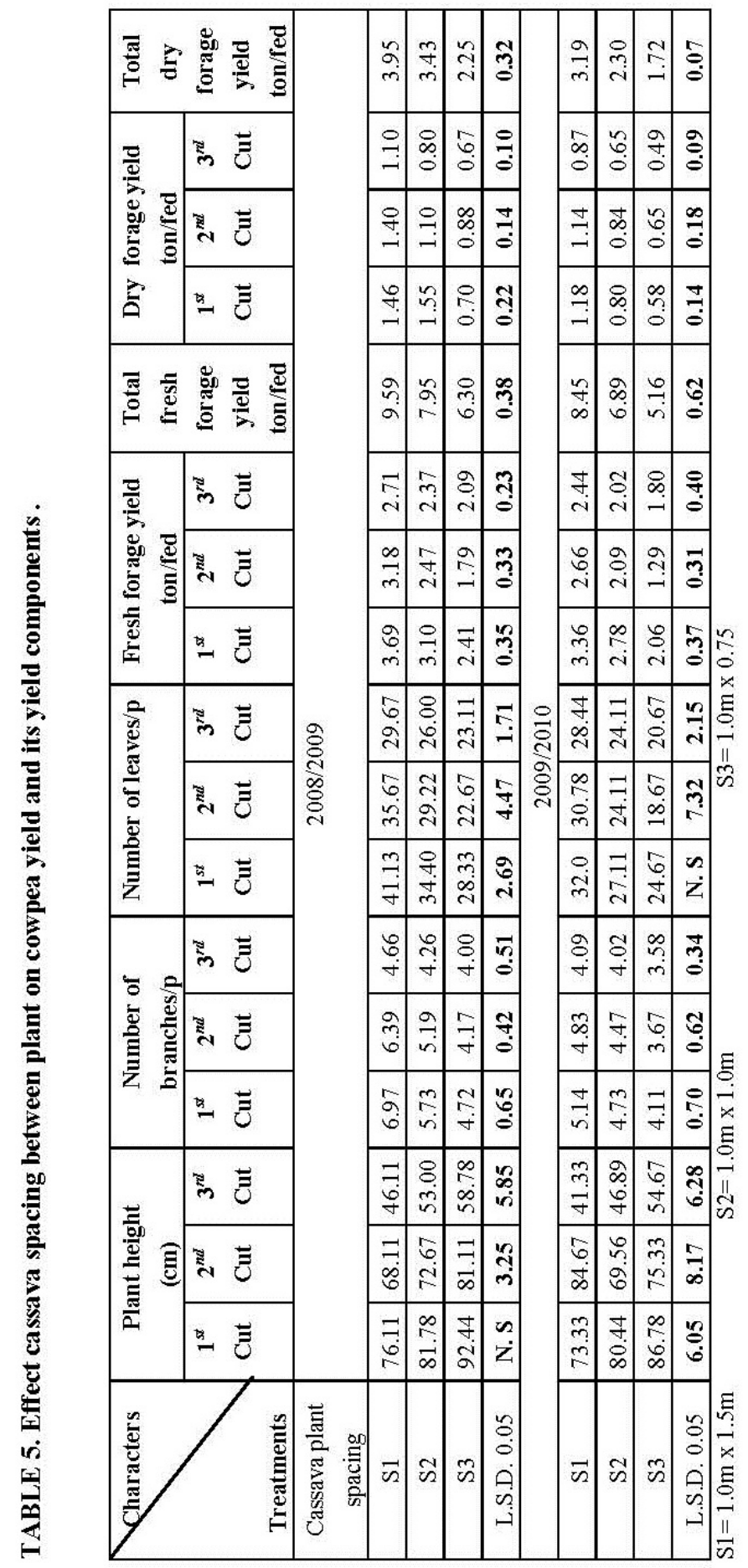

Egypt. J. Agron. 33, No.1 (2011) 
Effect of fodder cowpea plant densities on cowpea yield and its components

Data in Table 6 revealed that plant height of fodder cowpea increased significantly by increasing fodder cowpea plant density for each of the three cuts in each seasons. Data showed that maximum increase was observed with the highest fodder cowpea plant density (D3=42000plant/fed), whereas, the maximum decrease was observed at the lowest density (D1= 21000 plant/fed). These differences mainly due were to increase in fodder cowpea plant densities due to the less light interception by foliage. These results are in agreement with those obtained by Abd El-Shafy et al. (2009). They concluded that low light intensity intercepted by foliage enlarged stem internodes and consequently increased plant height. Also, data revealed that number of branches and leaves per plant were also significantly influenced by fodder cowpea plant density for each of the three fodder cowpea cuts in each season. Data showed gradual increase in the number of branches and leaves per plant with increasing fodder cowpea density. Maximum values were produced at the highest density (D3= 42000plant/fed). However, the moderate density value (D2= 28000plant/fed) ranked the second, while the minimum values were produced at the lowest density (D1=21000plant/fed). These results were supported by Muhammad et al. (2006). Data also revealed that the first fodder cowpea cut for each of the two seasons gave the highest fresh forage yield compared with the other two cuts. Highest plant density was superior for the three cuts in forage production. Moreover, it produced the highest total fresh forage yield in each of the two seasons. Whereas, the lowest density produced the lowest forage yield. The increases in total fresh forage yield at highest density (D3 $=42000$ plant/fed) compared with the lowest density (D1=21000plant/fed) were estimated to 126.65 and $127.40 \%$ in first and second seasons, respectively. Furthermore, dry forage yield in the three cuts and the total dry forage yield followed the same trend as the effect on the fresh forge yield in the two seasons. These results are in agreement with those of Muhammad et al. (2006).

Interaction effect of spacing between cassava plants and fodder cowpea population densities on cowpea yield and its components

All traits of the studied were insignificantly affected by the interaction of the two main variables in the two seasons except in cases of total dry forage yield and dry forage yield of the first and second cuts in the second season. Data in Table 7 revealed that there were increases in all traits of yield and yield components when fodder cowpea plants were grown with cassava at the lowest cassava spacing with highest fodder cowpea density. These results were true for the three cuts of fodder cowpea in the two seasons, whereas, the lowest values were observed when fodder cowpea was grown at lowest density with the highest cassava spacing. 
STUDIES ON CASSAVA (MANIHOT ESCULENTA CRANTZ) ...

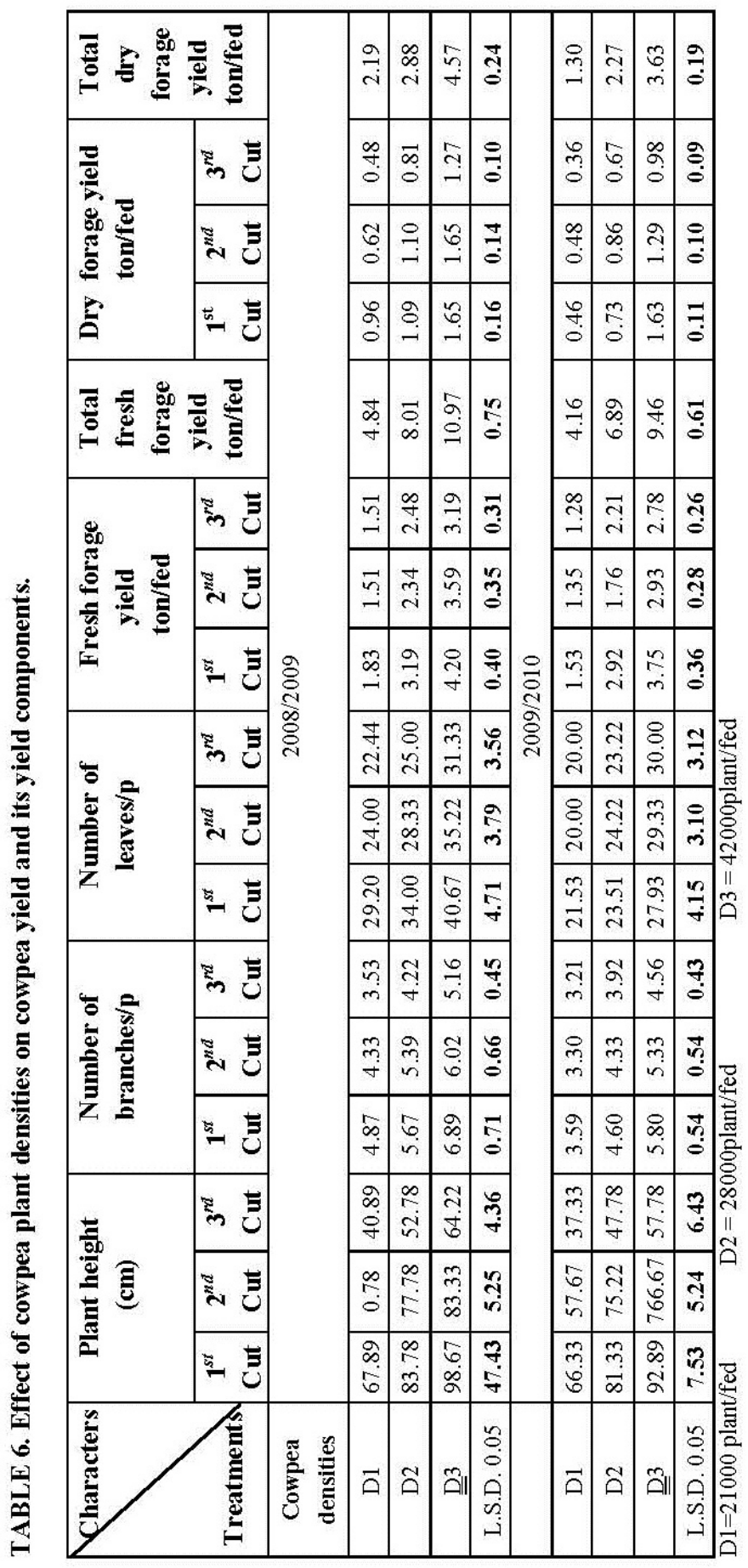

Egypt. J. Agron . 33, No.1 (2011) 


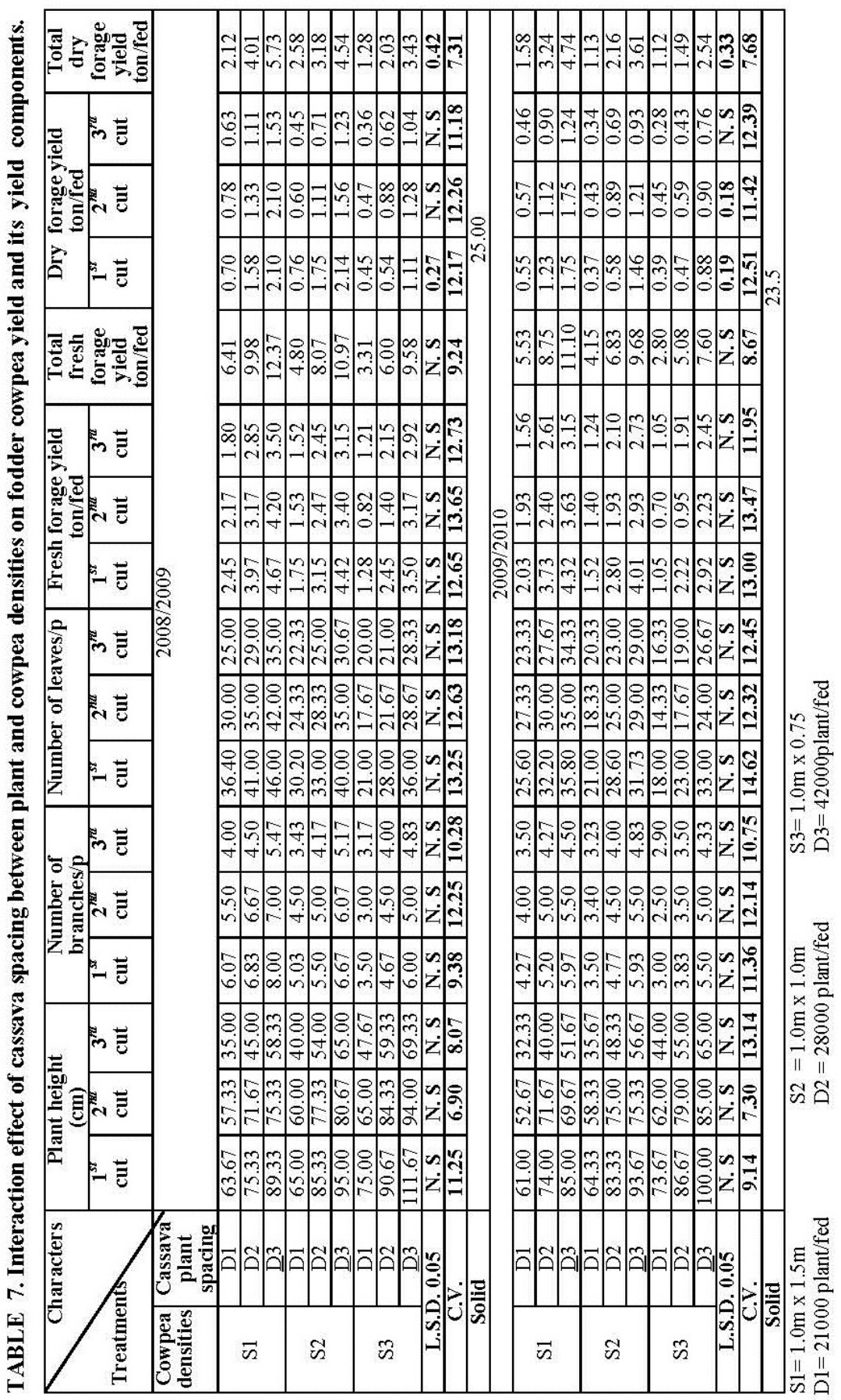

Egypt. J. Agron . 33, No. 1 (2011) 
Interaction effect of cassava plant spacing and cowpea plant densities on the competitive relationships of cassava intercropped with fodder cowpea

Land equivalent ratio (LER)

Data in Table 8 indicated that most imposed of treatments achieved yield advantage. The highest values of cassava relative yield were 1.28 and 1.38 in the first and second season, respectively were recorded when cassava was spaced at lowest spacing ( $\mathrm{S} 3=1.0 \mathrm{~m} \times 0.75 \mathrm{~m}$ ) and intercropped with the highest cowpea plant density $(\mathrm{D} 3=42000$ plants/fed), whereas the lowest values in the two seasons respective were 0.47 and 0.56 which was recorded when cassava was spaced at lowest spacing $(\mathrm{S} 1=1.0 \mathrm{~m} \times 1.5 \mathrm{~m})$ and intercropped with the lowest fodder cowpea plant density $(\mathrm{D} 1=21000)$ plants/fed).

TABLE 8. Interaction effect of cassava plant spacing and cowpea plant densities on competitive relation .

\begin{tabular}{|c|c|c|c|c|c|c|c|c|c|c|c|}
\hline & & \multicolumn{2}{|c|}{ Yield } & \multicolumn{2}{|c|}{ Relative yield } & \multirow{2}{*}{ LER } & \multicolumn{2}{|c|}{ Competitive ratio } & \multirow[b]{2}{*}{ CR } & \multicolumn{2}{|c|}{ Aggresivity } \\
\hline & & \begin{tabular}{|c|}
$\begin{array}{c}\text { Cassava } \\
\text { ton/fed }\end{array}$ \\
\end{tabular} & \begin{tabular}{|c|}
$\begin{array}{c}\text { Cowpea } \\
\text { ton/fed }\end{array}$ \\
\end{tabular} & Cassava & Cowpea & & \begin{tabular}{|l|} 
Cassava \\
\end{tabular} & Cowpea & & Cassava & Cowpea \\
\hline $\begin{array}{c}\text { Cassava } \\
\text { plant } \\
\text { spacing }\end{array}$ & $\begin{array}{c}\text { Cowpea } \\
\text { densities }\end{array}$ & \multicolumn{10}{|c|}{$2008 / 2009$} \\
\hline \multirow{3}{*}{ S1 } & D1 & 7.08 & 6.41 & 0.47 & 0.26 & 0.73 & 0.67 & 1.47 & 2.14 & -0.33 & +0.33 \\
\hline & D2 & 8.33 & 9.98 & 0.56 & 0.40 & 0.96 & 1.05 & 0.95 & 2.00 & +0.04 & -0.04 \\
\hline & D3 & 9.58 & 12.37 & 0.64 & 0.50 & 1.14 & 1.43 & 0.69 & 2.12 & +0.29 & -0.29 \\
\hline \multirow{3}{*}{ S2 } & D1 & 8.37 & 4.80 & 0.56 & 0.19 & 0.75 & 0.74 & 1.36 & 2.10 & -0.21 & +0.21 \\
\hline & D2 & 9.47 & 8.07 & 0.63 & 0.32 & 0.95 & 0.99 & 1.04 & 2.03 & -0.02 & +0.02 \\
\hline & D3 & 10.75 & 10.97 & 0.72 & 0.44 & 1.16 & 1.23 & 0.81 & 2.04 & +0.13 & -0.13 \\
\hline \multirow{3}{*}{ S3 } & D1 & 14.83 & 3.31 & 0.99 & 0.13 & 1.12 & 1.45 & 0.69 & 2.14 & +0.21 & -0.21 \\
\hline & D2 & 16.83 & 6.00 & 1.12 & 0.24 & 1.36 & 1.77 & 0.56 & 2.33 & +0.36 & -0.36 \\
\hline & D3 & 19.17 & 9.58 & 1.28 & 0.38 & 1.66 & 1.89 & 0.53 & 2.42 & +0.45 & -0.45 \\
\hline \multicolumn{2}{|c|}{ Solid } & 15.00 & 25.00 & & & & & & & & \\
\hline \multicolumn{12}{|c|}{$2009 / 2010$} \\
\hline \multirow{3}{*}{ S1 } & D1 & 8.00 & 5.53 & 0.56 & 0.23 & 0.79 & 0.90 & 1.10 & 2.00 & +0.55 & -0.55 \\
\hline & D2 & 9.42 & 8.75 & 0.66 & 0.37 & 1.03 & 1.34 & 0.75 & 2.09 & +0.27 & -0.27 \\
\hline & D3 & 10.67 & 11.10 & 0.75 & 0.47 & 1.22 & 1.79 & 0.56 & 2.35 & +0.10 & -0.10 \\
\hline \multirow{3}{*}{ S2 } & D1 & 9.17 & 4.15 & 0.64 & 0.18 & 0.82 & 0.89 & 1.12 & 2.01 & +0.29 & -0.29 \\
\hline & D2 & 10.25 & 6.83 & 0.72 & 0.29 & 1.01 & 1.24 & 0.80 & 2.04 & +0.14 & -0.14 \\
\hline & D3 & 11.50 & 9.68 & 0.81 & 0.41 & 1.22 & 1.49 & 0.63 & 2.12 & -0.01 & +0.01 \\
\hline \multirow{3}{*}{ S3 } & D1 & 15.50 & 2.80 & 1.09 & 0.12 & 1.21 & 1.73 & 0.59 & 2.32 & +0.66 & -0.66 \\
\hline & D2 & 14.42 & 5.08 & 1.01 & 0.22 & 1.23 & 1.74 & 0.59 & 2.33 & +0.47 & -0.47 \\
\hline & D3 & 19.67 & 7.60 & 1.38 & 0.32 & 1.70 & 2.41 & 0.41 & 2.82 & +0.61 & -0.61 \\
\hline \multicolumn{2}{|c|}{ Solid } & 14.25 & 23.50 & & & & & & & & \\
\hline \multicolumn{2}{|c|}{$\begin{array}{l}\mathrm{S} 1=1.0 \mathrm{~m} \times 1.5 \mathrm{~m} \\
\mathrm{D} 1=21000 \mathrm{p} / \mathrm{fed}\end{array}$} & & $\begin{array}{l}\mathrm{S} 2 \\
\mathrm{D} 2\end{array}$ & $2=2800$ & $\begin{array}{l}x 1.0 \mathrm{~m} \\
0 \mathrm{p} / \mathrm{fed}\end{array}$ & & & $\begin{array}{l}\mathrm{S} 3=1.0 \\
\mathrm{D} 3=42\end{array}$ & $\begin{array}{l}\times 0.7 \\
00 \mathrm{p} / \mathrm{fe}\end{array}$ & & \\
\hline
\end{tabular}

The highest values of fodder cowpea relative yield were 0.50 and 0.47 in the first and second season, respectively when fodder cowpea was sown at the highest plant density (D3= 42000 plant/fed) and intercropped with highest cassava plant spacing $(\mathrm{S} 1=1.0 \mathrm{~m} \times 1.5 \mathrm{~m})$, whereas the lowest values in the respective two seasons were 0.13 and 0.12 when fodder cowpea was sown at the lowest cowpea plant density (D1=21000 plant/fed) and intercropped with lowest cassava plant spacing $(\mathrm{S} 3=1.0 \mathrm{~m} \times 0.75 \mathrm{~m})$. 
The LER values were almost greater than unit, except, in some cases in the first and second seasons. Also data revealed that the best performance was associated with cassava spaced at a distance of $(1 \mathrm{~m} \times 0.75 \mathrm{~m})$ and intercropped with highest fodder cowpea plant density (42000 plants/fed) in both seasons which achieved benefit estimated to be $66 \%$ in the first season and $70 \%$ in the second one. These results are in agreement with those obtained by Ali et al. (2007).

\section{Competitive ratio $(C R)$}

The competitive ratio is an important tool to know the degree of which one crop competes with the other (Table 8). Cassava recorded higher values for CR than fodder cowpea in almost of the treatments except in cases when cassava spaced at highest spacing $(\mathrm{S} 1=1.0 \mathrm{~m} \times 1.5 \mathrm{~m})$ and intercropped with fodder cowpea sown at lowest and medium plant density (D1= 14000 and D2= 28000plant/fed) in first and second seasons and when cassava spaced at the medium spacing $(\mathrm{S} 2=1.0 \mathrm{~m} \times 1.0 \mathrm{~m})$ and intercropped with fodder cowpea at lowest and medium plant densities (D1= 14000 and D2 $=28000$ plant $/ \mathrm{fed}$ ). These results indicated that cassava was more competitive than fodder cowpea. The lowest competitive ratio of fodder cowpea was recorded when it was sown at highest plant density (D3= 42000plant/fed) and intercropped with cassava spaced at distance of $(\mathrm{S} 1=1.0 \mathrm{~m} \times 1.5 \mathrm{~m})$ in the two seasons, whereas, the highest competitive ratio of cassava was recorded when cassava was planted at the lowest plant spacing $(\mathrm{S} 3=1.0 \mathrm{~m} \times 0.75 \mathrm{~m})$ and intercropped with fodder cowpea at the highest plant density (D3=42000plant/fed). These results were true in both of the growing seasons.

Aggressivity (A)

Data on the aggressivity revealed that obtained values for cassava were positive in almost cases, except when cassava plants were grown at lowest space $(\mathrm{S} 1=1.0 \mathrm{~m} \times 1.5 \mathrm{~m})$ and intercropped with fodder cowpea at lowest plant density (D1= 21000 plant/fed) and when cassava plants were grown at the medium spacing $(\mathrm{S} 2=1.0 \mathrm{~m} \times 1.0 \mathrm{~m})$ and intercropped with cowpea at lowest and medium plant densities $(\mathrm{D} 1=21000$ and D2 $=28000$ plant $/$ fed $)$ in first season, and when cassava plants were grown at medium spacing $(\mathrm{S} 2=1.0 \mathrm{~m} \times 1.0 \mathrm{~m})$ intercropped with fodder cowpea at highest plant density (D3=42000plant $/$ fed) in second season. It means that cassava was the dominant and fodder cowpea was dominated. Similar results were observed by Sherif (2000)

\section{References}

Abd El-Shafy, A.S., Tarrad, M.M. and Fahmy, A.H. (2009) Effect of intercropping patterns of teosinte with cowpea on yield, quality and their competitive relationships. Annals of Agric. Sci., Moshtohor, 47(3), 215-224.

Aigh, B.F. (2007) The role of tropical legumes in improving soil fertility and crop production. Plant and Soil Science, 3, 224-229. 
Ali, M.O., Alam, M.J., Alam, M. S., Islam, M. A. and Shahin-uz-Zaman, M. (2007) Study on mixed cropping mungbean with sesame at different seeding rates. Int. J. Sustain. Crop Prod. 2(5), 74-77.

Amanullah, M. M., Vaiyapuri, K., Alagesan, A., Somasundaram, E., Sathyamoorthi, K. and Pazhanivelan, S. (2006b) Effect of intercropping and organic manures on the yield and biological efficiency of cassava intercropping system (Manihot esculenta Crantz). Research Journal of Agriculture and Biological Sciences, 2, 201-208.

Ayoola, O.T. and Makinde, E.A. (2008) Influenced of cassava population density on the growth and yield performance of cassava - maize intercrop with a relayed cowpea. Tropical and Subtropical Agro ecosystems, 8, 235 - 241.

Cenpukdee, U. and Fukai, S. (1992) Cassava /Legume intercropping with contrasting cassava cultivars. 1. Competition between crops under three intercropping conditions. Field Crops Res., 29, 113-133.

Eke-Okoro, O.N., Ikeorgu, J.E.G and Okorocha, E.O.A. (1999) Comparative evaluation of five legume species for soil fertility improvement, weed suppression and component crop yields in cassava/legume intercrops. Afr. J. Root Tuber Crops, 3(2), 17-54.

Fonseca, D. (1981) Effects of population and special arrangement of cowpea (Vigna unguiculata) and peanut (Arachis hypogea) grown in association with cassava (Manihot esculanta Crantz) on production and intensity of land use, in: CassavaCowpea and Cassava-Peanut Intercropping 1. Yield and Land Use Efficiency (Ed. Mason, S.C., Leihner, D.E. and Vorst.), Agron. J. 78 (43-46).

Ibrahim, Sahar T., Sherif, Sahar A. and Kamel, A. S. (2004) Effect of planting date and plant spacing on growth yield and yield components of cassava plants as new crop in Toshky region, Egypt. Proceedings of $2^{\text {nd }}$ Australian New Crops Conference, $20-$ 24 September.

Ikeorgu, J.E.G. and Odurukwe, S.O.(1990) Increasing the productivity of cassava/maize intercrop with groundnut. Trop. Agric. Trinidad, 67, 164-168.

International Institute of Tropical Agriculture (IITA) (1985) Annual Report. International Institute of Tropical Agriculture, Ibadan, Nigeria

Gerh, S.R., Lot, F.M. and Aarh, T.T. (2006) The effects of different plant studies on chemical and biological properties of an alfisol. Soil Science Research, 6 (4) 501-506.

Khalil, A. A. M. (1995) Agronomic studies on cassava plant, Ph. D. Thesis, Fac. Agric. Zagazig, Zagazig University, Zagazig, Egypt.

Kurtz, L.A. (2006) The yield and yield indices of cassava as affected by increasing planting densities of cowpea in a cassava/cowpea mixture. Crop Husbandry Research, 1, 90-95. 
Leihner, D. (1983) "Management and Evaluation of Intercropping Systems with Cassava”. CIAT, Cali., Colombia, 70 pp.

Mc Gilichrist, C. A. (1965) Analysis and competition experiments, Biometrics, 21, 975-985.

Mead, R. and Willey, R.W. (1980) The concept of a "land equivalent ratio" and advantages in yield from intercropping. Exp. Agric. 16, 217-218.

Moreira, N. (1989) The effect of seed rate and nitrogen fertilizer on the yield and nutritive value of oat-vetch mixtures. J. Agric. Sci. Camb. 112(1), 57-66.

MSTAT (1986) A microcomputer program of the Design Management and Analysis of Agronomic Research Experiments. Michigan State Univ., USA.

Muhammad, I., Rafiq, M., Sultan, A., Akram, M. and Goheer, M. A. (2006) Green fodder yield and quality evaluation of maize and cowpea sown alone and in combination. J. Agric. Res. 44(1).

Muleba, N. and Ezumah, H.C. (1985) Optimizing cultural practices for cowpea in Africa. In: "Cowpea Research, Production and Utilization". John Wiley and Sons. pp. 289-295.

Njoku, D.N., Afuape, S.O. and Ebeniro, C.N. (2010) Growth and yield of cassava as influenced by grain cowpea population density in Southeastern Nigeria. African Journal of Agricultural Research 5(20), 2778-2781.

Okigbo, B.N.(1980) The importance of mixed stands in tropical agriculture. In: R.G. Hurd, P.V. Biscoe and C. Dennis (Editors), Proc. 25 ${ }^{\text {th }}$ Anniversary Meeting, Association of Applied Biology, Univ. of Reading, 17-21 September 1979. Pitman, London, pp. 233-245. 18 October 2010.

Sherif, Sahar A. (2000) Intercropping Cassava with Nigerian cowpea under different fertilizer rates in sandy soil Ph.D.Thesis, Institute of African Research and Studies. Natural Resources Department Cairo University, Cairo, Egypt.

Snedecor, G.W. and Cochran, W.G. (1982) “Statistical Methods”, $6^{\text {th }}$ ed. pp. 325-330. The Iowa State Univ. Press, Ames, Iowa, USA.

Steiner, K.G. (1991) Overcoming soil fertility constraints to crop production in West Africa: Impact of traditional and improved cropping systems on soil fertility. In: "Alleviating Soil Fertility Constraints to Increased Crop Production in West Africa" Mokwunye, A.U. Ed.) pp. 69-91., FAO. Nigeria.

Udeata, R.O. (2005) Effects of increasing groundnut planting densities in a cassava/groundnut intercrop on yield and yield components of cassava in northeastern Zimbabwe. Journal of Agricultural Science and Environment, 3(2), 266-271.

Willey, R.W. and Rao, M.R. (1980) A competitive ratio for quantifying competition between intercrops. Exp. Agric. 16, 117-125.

Egypt. J. Agron . 33, No. 1 (2011) 
Zoufa, K., Tariah, N.M. and Isirimah, N.D. (1992) Effects of groundnut, cowpea and melon on weed control and yield of intercropping cassava and maize. Field Crops Research, 28, 309-314.

\section{دراسات على تحميل الكسافا مع لوبيا العلف فى الأراضي الرملية

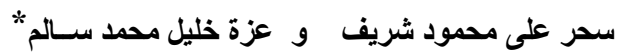

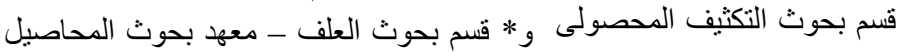 \\ الحقلية ـمركز البحوث الزر اعية ــ الجيزة ـ- مصر.}

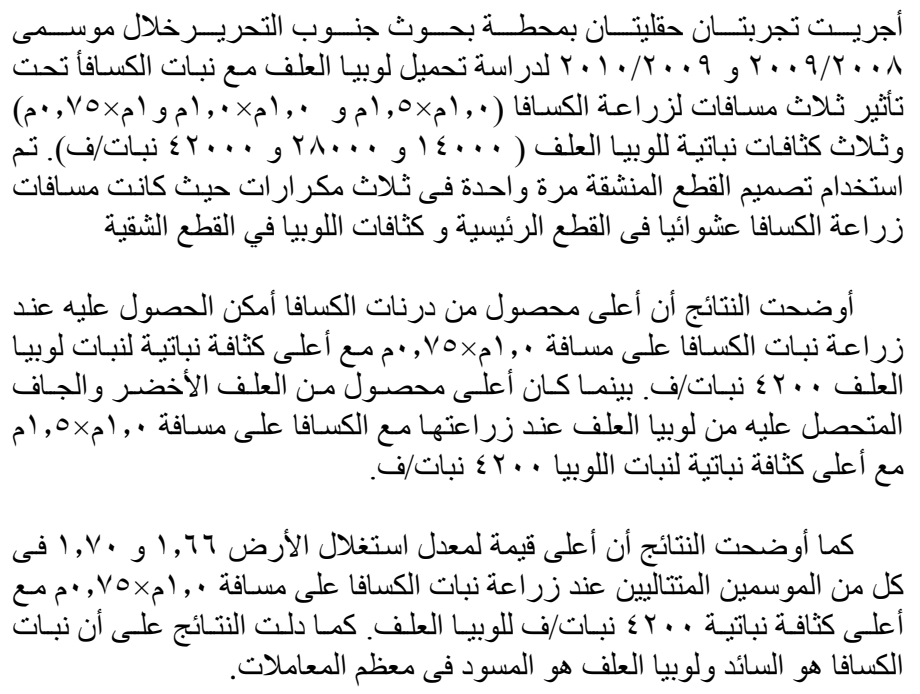

